\title{
Evaluation of protein extraction methods for enhanced proteomic analysis of tomato leaves and roots
}

\author{
MILCA B. VILHENA, MÔNICA R. FRANCO, DAIANA SCHMIDT, \\ GISELLE CARVALHO and RICARDO A. AZEVEDO
}

ESALQ/USP - Escola Superior de Agricultura "Luiz de Queiroz", Universidade de São Paulo, Departamento de Genética 11, Caixa Postal 83, 13400-970 Piracicaba, SP, Brasil

Manuscript received on February 18, 2015; accepted for publication on March 18, 2015

\begin{abstract}
Proteomics is an outstanding area in science whose increasing application has advanced to distinct purposes. A crucial aspect to achieve a good proteome resolution is the establishment of a methodology that results in the best quality and wide range representation of total proteins. Another important aspect is that in many studies, limited amounts of tissue and total protein in the tissue to be studied are found, making difficult the analysis. In order to test different parameters, combinations using minimum amount of tissue with 4 protocols for protein extraction from tomato (Solanum lycopersicum L.) leaves and roots were evaluated with special attention to their capacity for removing interferents and achieving suitable resolution in bidimensional gel electrophoresis, as well as satisfactory protein yield. Evaluation of the extraction protocols revealed large protein yield differences obtained for each one. TCA/acetone was shown to be the most efficient protocol, which allowed detection of 211 spots for leaves and 336 for roots using $500 \mu \mathrm{g}$ of leaf protein and $800 \mu \mathrm{g}$ of root protein per gel.
\end{abstract}

Key words: bidimensional electrophoresis, proteins, protocol optimization, tomato.

\section{INTRODUCTION}

The amplification of gene action in an eukaryotic cell is mostly due to the existent variety of translational and post-translational processes, which can form a great number of proteins (isoforms) from a single gene (Wouters et al. 2013). The final result is a highly specific pool of proteins differing among cell types and conditions to which they are exposed. In order to study the translational results of any given condition, proteomic techniques are being widely used (Rose et al. 2012, Arruda et al. 2013). However, twodimensional electrophoresis (2-DE) is not a simple technique and according to the sample preparation, the

Correspondence to: Ricardo A. Azevedo

E-mail:raa@usp.br results can be quite different indicating the need for well optimized procedures that include repeatability and reproducibility (Barbosa et al. 2013, Tabb 2013).

With regard to the plant material, each tissue has its own peculiarities, for instance, when targeting the root tissue, protein concentration is a crucial problem when compared to leaf tissue, whereas the latter presents large amounts of nonprotein components or interferents, which can compromise twodimensional gel electrophoresis (2-DE) separation (da Silva et al. 2009).

Sample preparation, which is crucial for proteomic analysis, consists of 3 major steps: protein extraction, removal of interferents and protein resolubilization in a buffer solution (Tabb 2013). 
Although there are several sample preparation protocols available in the literature (Palma et al. 2011, Rodrigues et al. 2012), protocols specifically designed for tomato species (Solanum lycopersicum L.) are not well defined.

Tomato is an economically relevant crop of great importance in the human diet, and is a major crop plant and a model system for fruit development (Gratão et al. 2012, TGC 2012). The tomato cultivar Micro-Tom (MT) has been successfully used as a model plant to explore several aspects of plant development due to important characteristics such as a short developmental cycle (Meissner et al. 1997). Additionally, a MT mutant collection with other tomato lines are available at "HCPD-Lab Micro-Tom Mutants", which has been explored for different features, hormonal (Monteiro et al. 2011, Carvalho et al. 2013) and metal (Gratão et al. 2009, Dourado et al. 2013, 2014, Nogueirol et al. 2015) responses and biochemical and histological characterization (Monteiro et al. 2012). However, since the complete tomato genome sequence was published (TGC 2012), reports have focused on genetic and genome features and little information with a focus on proteome is available.

Due to the importance of comprehensive proteomic studies, this study reports the evaluation of 4 main protocols available for tomato leaves and roots protein extraction for optimal twodimensional electrophoresis. In spite of the fact that we selected total protein extraction protocols, to our knowledge, this methodological study may help other researchers to use the established method for different purposes not only for tomato species, but also for pepper, eggplant and so forth.

\section{MATERIALS AND METHODS}

Plant MATERIAL

Tomato plants (Solanum lycopersicum L.) - MT cultivar - were cultivated in a greenhouse (Piracicaba, Departamento de Genética - ESALQ/USP) in trays with vermiculite at average temperatures of 18 to
$24{ }^{\circ} \mathrm{C}$ approximately (night and day, respectively). Irrigation was carried out daily using tap water until germination ( 15 days approximately). Thereafter, the plants were transferred to a hydroponic system using Hoagland and Arnon (1950) solution, initially at a low concentration (10\%), which was increased daily to $50 \%$ so that the plants would best adapt to this salt solution. A total of 5 plants were harvested (30 days of age approximately), pooled and immediately frozen in liquid nitrogen and stored at $-80^{\circ} \mathrm{C}$.

Reagents used in electrophoretic separation (acrylamide, DTT, iodoacetamide, urea, thiourea, ampholytes, strips for isoelectric focusing and mineral oil) were from Bio-Rad (Hercules, CA, USA) and GE healthcare (Freiburg, Germany). All other chemicals (including mineral acids, reagents for buffers preparation and gel stain) were obtained from Sigma-Aldrich (Steinheim, Germany) and Merck (Darmstadt, Germany). All solutions were prepared with deionized-autoclaved water $(\geq 18.2$ $\mathrm{M} \Omega \mathrm{cm}$ ) using a Milli-Q water purification system (Millipore, Bedford, USA).

\section{PROTEIN EXTRACTION}

The plant tissues (roots and leaves) were grounded in a mortar with liquid nitrogen added with $10 \%$ PVPP. Five hundred $\mathrm{mg}$ of fresh leaf and $1.5 \mathrm{~g}$ of fresh root were weighed in ice-cold centrifuge tubes ( 3 replicates) to which the extraction buffer solution (Table I) was added and homogenized (each protocol used a different period and method). As an alternative procedure, although we did not employ it in this study, the extractor buffer can be directly added to the mortar containing the sample, which might result in better protein extraction efficiency. The 4 different protocols were tested as follows:

Protocol 1 - TCA/Acetone method: Ten $\mathrm{mL}$ of ice-cold precipitation solution (Table I) were added to the plant tissue in centrifuge tubes immersed in ice (40 $\mathrm{mL}$ capacity) and briefly homogenized in vortex. Tubes were placed in the freezer at $-20^{\circ} \mathrm{C}$ for 
$2 \mathrm{~h}$. The remaining insoluble material was removed by centrifugation at $21,000 \mathrm{x} g$ at $4{ }^{\circ} \mathrm{C}$ for $30 \mathrm{~min}$. The pellet obtained was washed twice with $10 \mathrm{~mL}$ of ice-cold solution $(0.07 \% \beta$-mercaptoethanol $(\beta$ $\mathrm{ME})$ in acetone) with $2 \mathrm{~h}$ intervals at $-20{ }^{\circ} \mathrm{C}$ and then centrifuged at $21,000 \mathrm{x} g$ at $4{ }^{\circ} \mathrm{C}$ for $30 \mathrm{~min}$. The supernatant was gently discarded in order to maintain the pellet integrity. The sample was then placed in a vacuum desiccator at $4{ }^{\circ} \mathrm{C}$ for 2 days for complete drying.

TABLE I

Description of buffer composition and volume used.

\begin{tabular}{|c|c|c|}
\hline Extraction Buffer & Composition & Volume used \\
\hline $\begin{array}{l}\text { TCA/Acetone }(\mathbf{P 1}) \\
\text { Xu et al. }(2008)\end{array}$ & $\begin{array}{l}10 \% \text { Trichloroacetic acid (TCA); } \\
0.07 \% \beta \text {-ME in Acetone P.A. }\end{array}$ & $10 \mathrm{~mL}$ \\
\hline $\begin{array}{c}\text { Phenol (P2) } \\
\text { Amalraj et al. (2010) }\end{array}$ & $\begin{array}{l}\text { 0.7 M Sucrose; } 0.5 \text { M Tris; } 50 \text { mM EDTA; } \\
1 \text { mM PMSF }{ }^{(1)} ; 2 \% \beta \text {-mercaptoethanol } \\
\quad(\beta-M E) ; \text { phenol }^{(2)} . \mathrm{pH} 7.5\end{array}$ & $15 \mathrm{~mL}$ \\
\hline $\begin{array}{l}\text { Tris /TCA (P3) } \\
\text { Lee et al. (2011) }\end{array}$ & $\begin{array}{l}100 \mathrm{mM} \text { Tris; } 5 \mathrm{mM} \text { DTT; } 1 \text { mM EDTA; } \\
1 \mathrm{mM} \mathrm{PMSF}(1) \text { TCA in Acetone }{ }^{(3)} \cdot \mathrm{pH} 8.5\end{array}$ & $8 \mathrm{~mL}$ \\
\hline $\begin{array}{l}\text { Tris-base (P4) } \\
\text { Xu et al. (2008) }\end{array}$ & $\begin{array}{l}40 \text { mM Tris; } 5 \text { M Urea; } 2 M \text { Thiourea; } \\
2 \% \text { CHAPS; } 5 \% \text { PVP; } 2 \% \beta-M E\end{array}$ & $4 \mathrm{~mL}$ \\
\hline
\end{tabular}

Protocol 2 - Phenol method: Tubes with sample and extraction solution (Table I) immersed in ice were homogenized in a shaker at $70 \mathrm{rpm}$ for $30 \mathrm{~min}$. Buffered phenol $(15 \mathrm{~mL})$ was added to each tube immersed in ice and left for $30 \mathrm{~min}$ in a shaker. Samples were centrifuged at 10,000 x $g$ at $4{ }^{\circ} \mathrm{C}$ for $30 \mathrm{~min}$ and the supernatant transferred to another tube. Two $\mathrm{mL}$ of phenol and $15 \mathrm{~mL}$ of extraction solution were added to the tubes and homogenized in a shaker for $30 \mathrm{~min}$ inside foam with ice. Another step of centrifugation was performed. The phenol extract was transferred and divided into 2 new tubes and the tube volume was completed with $0.1 \mathrm{M}$ ammonium acetate (in 100\% methanol), mixed and incubated at $-20{ }^{\circ} \mathrm{C}$ overnight. The mixture was centrifuged at $16,000 \times \mathrm{g}$ for $20 \mathrm{~min}$ at $4{ }^{\circ} \mathrm{C}$ and the supernatant discarded. Pellets were covered with $40 \mathrm{~mL} 0.1 \mathrm{M}$ ammonium acetate in $100 \%$ methanol. The samples were left to precipitate for 2 to $3 \mathrm{~h}$ at $-20{ }^{\circ} \mathrm{C}$ and then centrifuged at $16,000 \times \mathrm{g}$ for $20 \mathrm{~min}$ at $4{ }^{\circ} \mathrm{C}$.
This step was repeated twice and then the pellet was left to dry in a vacuum desiccator at $4{ }^{\circ} \mathrm{C}$ for 2 days.

Protocol 3 - Tris/TCA method: Extraction solution (Table I) was added to the samples and the tubes were agitated for $15 \mathrm{~min}$ in a shaker with ice. The mixture was centrifuged at $12,000 \times \mathrm{g}$ for $30 \mathrm{~min}$ at $4{ }^{\circ} \mathrm{C}$. The supernatant was divided into 2 new tubes and to each tube $30 \mathrm{~mL}$ of $20 \%$ TCA in acetone was added, mixed and incubated overnight at $-20{ }^{\circ} \mathrm{C}$. The samples were centrifuged at $21,000 \mathrm{x}$ $g$ for 30 min at $4{ }^{\circ} \mathrm{C}$ and the supernatant discarded. Pellets were washed with an ice-cold solution of $0.07 \% \beta$-ME in acetone and then left to dry in a vacuum desiccator at $4{ }^{\circ} \mathrm{C}$ for 2 days.

Protocol 4 - Tris-base method: Four $\mathrm{mL}$ of extraction solution (Table I) were added to the plant tissue, briefly homogenized in vortex and centrifuged at $12,000 \times \mathrm{g}$ for $15 \mathrm{~min}$ at $4{ }^{\circ} \mathrm{C}$. The supernatant was recovered and $16 \mathrm{~mL}$ of washing solution $(0.07 \% \beta$-ME in acetone) was added. The 
mixture was incubated for $2 \mathrm{~h}$ minimum at $-20{ }^{\circ} \mathrm{C}$ and then centrifuged at $12,000 \times \mathrm{g}$ for $15 \mathrm{~min}$ at $4{ }^{\circ} \mathrm{C}$. This step was repeated twice to properly wash the pellet, and then the tubes were left to dry in a vacuum desiccator at $4{ }^{\circ} \mathrm{C}$ for 2 days. Regardless of the protocol, in order to speed up the drying process we suggest drying the spots using nitrogen gas (ca. $1 \mathrm{~min}$ ).
To guide the reader, a schematic representation of the 3 methodologies is presented in Figure 1.

PROTEIN SOLUBILIZATION AND QUANTIFICATION

After the pellets were completely dried, proteins were solubilized according to Amalraj et al. (2010) with a solubilization buffer (SB) consisting of $7 \mathrm{M}$ urea, $2 \mathrm{M}$ thiourea, 4\% CHAPS, $2 \%$ IPG

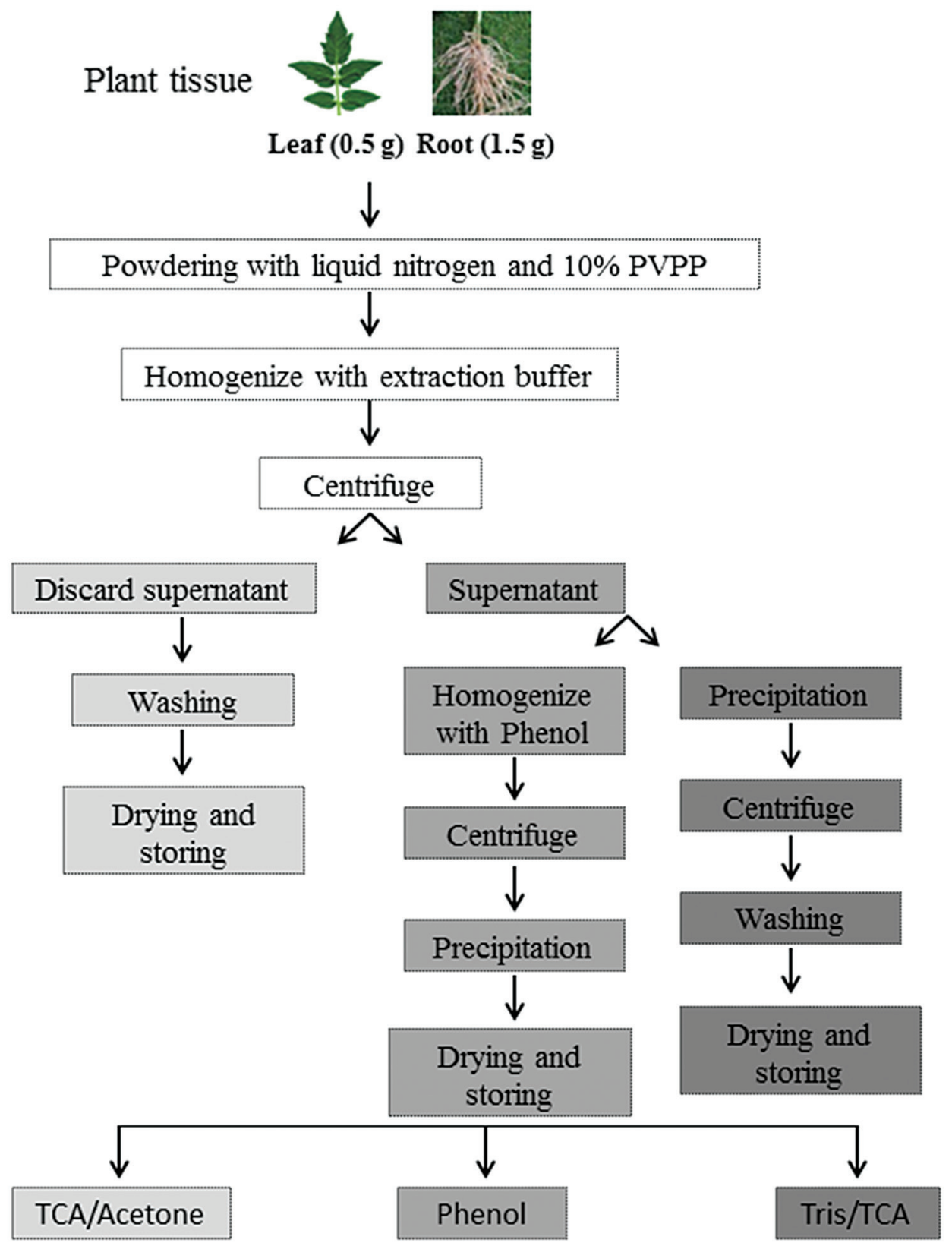

Figure 1 - Schematic outline of the 3 protein extraction methods tested. 
buffer and $0.3 \%$ DTT. SB solution $(2.0 \mathrm{~mL}-$ TCA; $450 \mu \mathrm{L}$ - Phenol; $300 \mu \mathrm{L}$ - Tris/TCA; and $300 \mu \mathrm{L}$ - Tris-base for $0.5 \mathrm{~g}$ of leaves, and $2.5 \mathrm{~mL}$ - TCA; $450 \mu \mathrm{L}$ - Phenol; $300 \mu \mathrm{L}$ - Tris/TCA; and $400 \mu \mathrm{L}$ - Tris-base for $1.5 \mathrm{~g}$ of roots) was added to the pellets and the mixture was vigorously stirred for $3 \mathrm{~min}$ and sonicated in cold water for $20 \mathrm{~min}$ for homogenization. The samples were centrifuged for 15 min at $21,000 \mathrm{x} g$ at $4{ }^{\circ} \mathrm{C}$, and the supernatant was recovered and transferred to a microtube, where it was additionally centrifuged for $10 \mathrm{~min}$ at 14,000 rpm at $4{ }^{\circ} \mathrm{C}$ to separate cell debris. After this second centrifugation the supernatant was transferred to a new microtube and stored at $-80{ }^{\circ} \mathrm{C}$ for further analysis. Total soluble protein concentration for all samples was determined by the Bradford method (1976) using bovine serum albumin as standard.

TWO-DIMENSIONAL GEL ELECTROPHORESIS

First-dimension separation was carried out using immobilized $\mathrm{pH}$ gradient IPG strips for isoelectric focusing - IEF (18 cm length, $\mathrm{pH}$ 3-10 NL, Immobiline DryStrip, GE Healthcare, Freiburg, Germany), rehydrated overnight with 2-DE buffer (7 M Urea, $2 \mathrm{M}$ Thiourea, 4\% Chaps, $0.5 \%$ Triton X-100, 50 mM DTT, 2\% IPG and $0.5 \%$ Bromophenol blue) containing $500 \mu \mathrm{g}$ and $800 \mu \mathrm{g}$ of leaf and root protein, respectively, resulting in a final volume of $375 \mu \mathrm{L}$. IEF was performed at $20{ }^{\circ} \mathrm{C}$ using an Ettan IPGphor 3 IEF system (GE Healthcare, Freiburg, Germany) testing 2 protocols:

a) Amalraj et al. (2010) modified nonlinear increase -4 h rehydration, step- $n$-hold at $30 \mathrm{~V}$ for $12 \mathrm{~h}$ (step 1 ), step- $n$-hold at $100 \mathrm{~V}$ for $1 \mathrm{~h}$ (step 2), step- $n$-hold at $200 \mathrm{~V}$ for $1 \mathrm{~h}$ (step 3), step- $n$-hold at $400 \mathrm{~V}$ for 1 h (step 4 ), step- $n$-hold at $700 \mathrm{~V}$ for $1 \mathrm{~h}$ (step 5), step- $n$-hold at $1000 \mathrm{~V}$ for $1 \mathrm{~h}$ (step 6), step- $n$-hold at $5000 \mathrm{~V}$ for $10 \mathrm{~h}$ (step 7), step- $n$-hold at $8000 \mathrm{~V}$ for 4 h (step 8), step- $n$-hold at $100 \mathrm{~V}$ for $3 \mathrm{~h}$ (step 9); b) Saravanan and Rose (2004) modified nonlinear increase $-1 \mathrm{~h}$ rehydration, 0 to $30 \mathrm{~V}$ over $12 \mathrm{~h}$ (step 1), 30 to $150 \mathrm{~V}$ over $1 \mathrm{~h}(\operatorname{grad} 2), 150$ to $300 \mathrm{~V}$ over $1 \mathrm{~h}(\operatorname{grad} 3), 300$ to $500 \mathrm{~V}$ over $1 \mathrm{~h}$ (grad 4), 500 to $3000 \mathrm{~V}$ over $2 \mathrm{~h}(\operatorname{grad} 5), 3000$ to $6000 \mathrm{~V}$ over $2 \mathrm{~h}$ (grad 6), 6000 to $10000 \mathrm{~V}$ over $2 \mathrm{~h}$ (grad 7), and then held at $10000 \mathrm{~V}$ for 7 h (step 8).

After isoelectric focusing, the proteins were reduced with $6 \mathrm{~mL}$ per strip of $0.05 \mathrm{M}$ Tris- $\mathrm{HCl}$ (pH 8.8) containing $6 \mathrm{M}$ Urea, 30\% Glycerol, 2\% SDS and $1 \%$ DTT. The proteins were then alkylated with $6 \mathrm{~mL}$ per strip of $0.05 \mathrm{M}$ Tris- $\mathrm{HCl}(\mathrm{pH} 8.8)$ containing 6 M Urea, 30\% Glycerol, 2\% SDS, 2.5\% Iodoacetamide and $0.002 \%$ Bromophenol blue, both with gently agitation at room temperature for $15 \mathrm{~min}$.

The second dimension separation was performed in a $12.5 \%$ polyacrylamide gel (GE Healthcare). Strips already equilibrated were horizontally accommodated at the top of the gels, sealed with $0.5 \%$ agarose solution and then placed in a gel cell with buffer solution ( $0.025 \mathrm{M}$ Tris, 0.192 $\mathrm{M}$ glycine, $0.1 \% \mathrm{SDS}-\mathrm{pH}$ 8.3). Electrophoresis was conducted at $4{ }^{\circ} \mathrm{C}$ using $15 \mathrm{~mA}$ per gel for 30 min, followed by an amperage increase to $30 \mathrm{~mA}$ per gel for 7h (Laemmli 1970).

Subsequently, proteins were fixed for $1 \mathrm{~h}$ in a solution containing $40 \%$ ethanol and $10 \%$ acetic acid prior to staining with $5 \%(\mathrm{w} / \mathrm{v})$ Coomassie blue G-250 for 12h (Candiano et al. 2004) under gentle agitation. Gels were then washed 3 times with Milli-Q water and immediately digitalized.

IMAGE ANALYSES

Images were digitalized in a scanner with LabScan 5.0 version software (Amersham Biosciences) and analyzed with the Image Master 2D Platinum 7 (GE Healthcare) software. All images were subjected to automatic detection of spots and to contrast settings, smooth (value: 7 - leaves; 6 roots), saliency (value: 100 - leaves; 120 - roots) 
and minimum area (value: 5 - leaves; 4 - roots). Subsequently, a manual curation was performed to confirm the veracity of spots, and to improve alignment between gel replicates for subsequent comparison between treatments.

\section{RESULTS}

The results (Fig. 2) showed that the Amalraj et al. (2010) IEF protocol was not suitable for the tomato species. The gels obtained with the Saravanan and Rose (2004) IEF protocol exhibited a higher number of spots, which were also better defined and more intense in comparison to the other IEF protocol.

Among the 4 protein extraction methods evaluated, TCA/Acetone resulted in the highest protein yields for both leaves and roots (Table II). Although presenting lower protein concentrations $\left(\mathrm{mg} \mathrm{mL}^{-1}\right.$ ) in relation to the other 3 methods, the
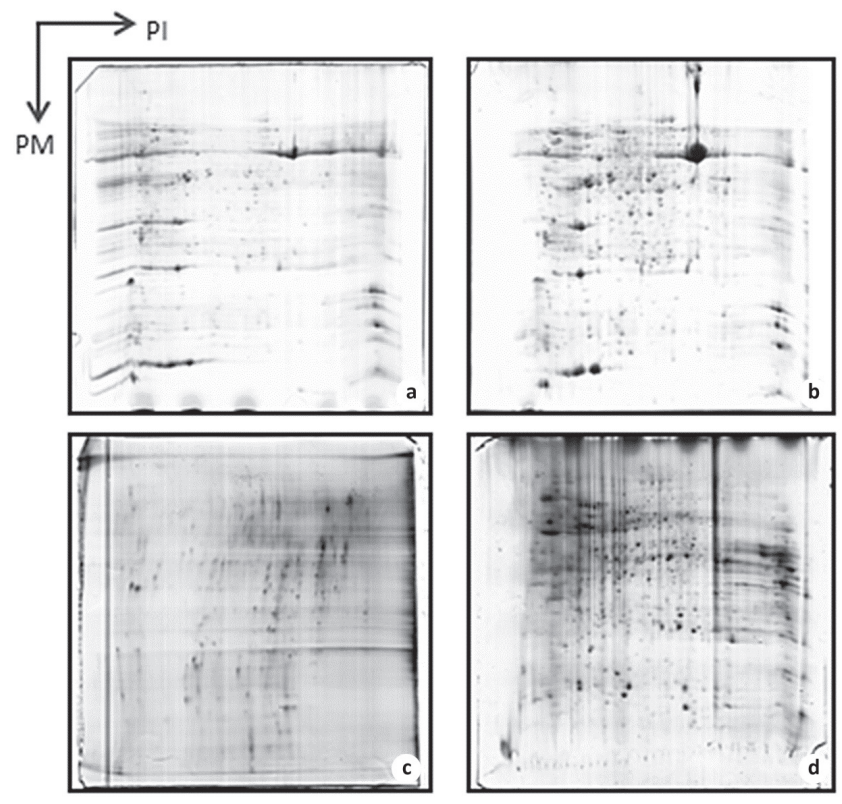

Figure 2 - 2-DE gel electrophoresis profiles of tomato cv. MT leaves (a and b) and roots (c and d) obtained with TCA/ Acetone resolved within an IEF pH range of 3-10. (a) and (c) were focused with Amalraj et al. (2010) IEF protocol; (b) and (d) were focused with Saravanan and Rose (2004) IEF protocol.

TABLE II

Mean quantification of total soluble proteins and protein yield using different extraction methods.

\begin{tabular}{|c|c|c|c|c|}
\hline \multirow{2}{*}{$\begin{array}{l}\text { Extraction } \\
\text { method }\end{array}$} & \multicolumn{2}{|c|}{$\begin{array}{c}\text { Total soluble protein } \\
\left(\mathrm{mg} \mathrm{mL}^{-1}\right)\end{array}$} & \multicolumn{2}{|c|}{$\begin{array}{l}\text { Protein yield } \\
\left(\mathrm{mg} \mathrm{gfw}^{-1}\right)\end{array}$} \\
\hline & Leaves & Roots & Leaves & Roots \\
\hline TCA/Acetone & $4.24 \mathrm{a}$ & $1.84 \mathrm{~b}$ & 16.96 & 3.06 \\
\hline Phenol & $10.60 \mathrm{ab}$ & $4.90 \mathrm{a}$ & 9.54 & 1.47 \\
\hline Tris/TCA & $14.24 \mathrm{a}$ & $2.73 \mathrm{~b}$ & 8.55 & 0.55 \\
\hline Tris-base & $8.07 \mathrm{~b}$ & $2.84 \mathrm{~b}$ & 4.84 & 0.76 \\
\hline
\end{tabular}

Means followed by the same letter in the same column did not differ statistically by Tukey test at $5 \%$ probability of error. higher values of protein yield $\left(\mathrm{mg} \mathrm{fw}^{-1}\right)$ were considered far more significant.

The Tris-base protocol (protocol 4) was tested several times and yielded suitable values of protein concentration, however, the extracts presented a large viscosity (gelatinous dark mass), which impaired sample isofocalization and gel separation. Such result did not allow any further use of this protocol, which was discarded from this study.

Gel images (Fig. 3, Fig. 4) enabled the observation of most proteins extracted with TCA/Acetone 
and Tris/TCA methods, as well as spot abundance and intensity. For both tissues, the majority of protein spots were present mainly in the 4-7 $\mathrm{pH}$ range of 2-DE.

There was no significant difference between numbers of protein spots (Table III) found for each extraction method.
TABLE III

Mean number of spots obtained from three replicates \pm standard deviation for each extraction method.

\begin{tabular}{ccc}
\hline \multirow{2}{*}{ Extraction method } & \multicolumn{2}{c}{ Spots } \\
\cline { 2 - 3 } & Leaves & Roots \\
\hline TCA/Acetone & $211 \pm 06$ & $336 \pm 28$ \\
Phenol & $214 \pm 22$ & $329 \pm 00$ \\
Tris/TCA & $248 \pm 33$ & $356 \pm 41$ \\
\hline
\end{tabular}
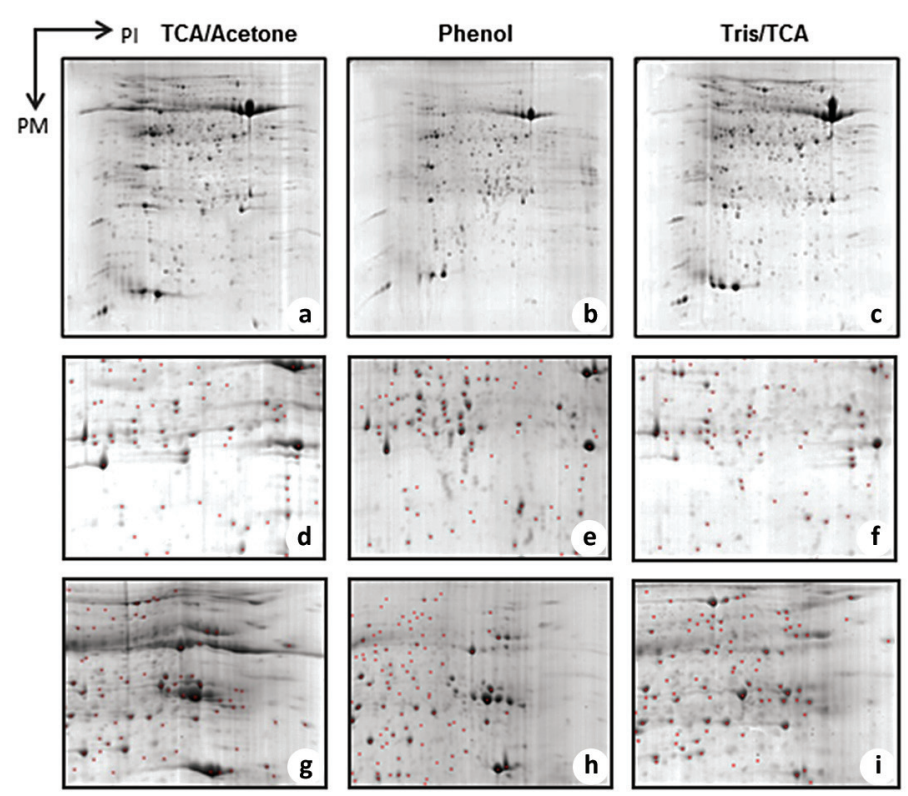

Figure 3 - 2-DE gel electrophoresis profiles of tomato cv. MT leaves obtained with TCA/Acetone, Phenol and Tris/TCA protocols (a, b and $\mathbf{c}$ ) respectively - resolved within an IEF $\mathrm{pH}$ range of 3-10. Representative gel regions zoomed to compare more closely differences in the extraction protocols (d to i).

\section{DISCUSSION}

The amount of fresh tissue to be used depends on the type of experiment to be carried out and may be a major obstacle in the reproducibility of a proteomic analysis. The most critical steps are protein extraction and sample preparation, especially in plants, which may present low protein content and produce several types of secondary metabolites (Luque-Garcia et al. 2011). Moreover, in a recent editorial paper published by Azevedo (2012), the "omics" procedures that are now available and largely employed by Brazilian research groups for a number of organisms, and other emerging techniques and their integration with different analytical techniques (metabolite measurements, gene expression analyses, enzymatic studies, etc) are essential to address key biological issues.

In previous studies extraction protocols have been tested (Sheoran et al. 2009, Pavoković et al. 2012, Rose et al. 2012). In this work we used the minimum plant material required $(0.5 \mathrm{~g}$ leaf and $1.5 \mathrm{~g}$ root) in all extractions tested to achieve a certain standard level, whereas in other papers higher amounts of material to perform the same technique were normally used (Saravanan and Rose 2004, Persia et al. 2008, da Silva et al. 2009, 

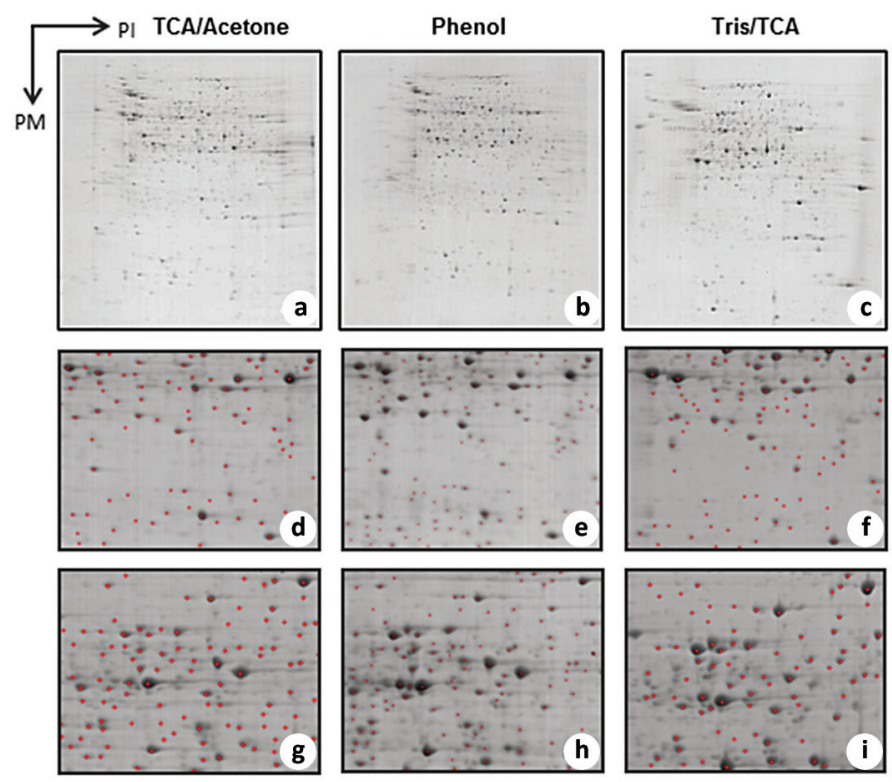

Figure 4 - 2-DE gel electrophoresis profiles of tomato cv. MT roots obtained with TCA/Acetone, Phenol and Tris/TCA (a, b and c) respectively - resolved within an IEF $\mathrm{pH}$ range of 3-10. Representative gel regions zoomed to compare more closely differences in the extraction protocols (d to i).

Kim et al. 2013). We developed a standardized 2-DE protocol to obtain accurate protein maps for tomato leaves and roots, starting from a minimum amount of plant tissue sufficient to perform gels in triplicates or quadruplicates, in association with a relatively simple method of extraction.

According to the gel images (Fig. 2), the Saravanan and Rose (2004) IEF protocol was much more efficient in separating tomato proteins in relation to that reported by Amalraj (2010), exhibiting a higher number of spots, which were also well defined and more intense, therefore, it was chosen to be used in all protein extractions henceforth. Perhaps this observed difference is due to the first protocol being based on a more smooth changing of voltage, which caused the tomato proteins to be more conserved.

Some modifications were applied to the IEF protocol described by Saravanan and Rose (2004), which resulted in approximately 200-400 wellresolved spots. It was also possible to notice that most spots were resolved within the 4-7 $\mathrm{pH}$ range. Our results are supported by Roan et al. (2013), who also found increased resolution of 2D gels by using $\mathrm{pH}$ 4-7 isoelectric focusing gels for papaya seeds. Therefore, for further analysis of tomato proteome we recommend the use of strips within this range for isofocalization.

In a primary analysis, by visually comparing the gels obtained for the 3 extraction methods, it is possible to infer that the Phenol method (Protocol 2) resulted in a smaller diversity of spots for both leaves and roots in relation to the TCA/Acetone and Tris/TCA methods (Protocols 1 and 3, respectively). However, according to the statistical analysis applied (Tukey test $-5 \%$ probability of error) the number of spots did not differ significantly among the 3 protocols.

It is known that the acetone based methods efficiently concentrate proteins while removing salts, sugars and some lipids (Pavlićević et al. 2013) and is also relatively faster than the Phenol method. 
However, a few lipids, such as phenolic compounds, remained as contaminants, interfering with the isoelectric focusing and causing some horizontal streaking (Fig. 3a, c). An important alteration in the TCA/Acetone protocol was to maintain the extraction cold during all steps, in order to prevent hydrophobic interactions and formation of complexes, thus enhancing the sample solubilization. We believe this to be one of the reasons why this method exhibited a wider range of protein types.

Although the Phenol method maximizes the elimination of interferents rendering sharply defined spots (Sheoran et al. 2009), it is quite time consuming and exhibited a smaller range of spots for tomato leaves and roots (Fig. 3, Fig. 4). The lower number of spots (except compared to TCA/Acetone for leaves) could be explained by lower detection of less abundant proteins (Lee et al. 2010).

The Tris/TCA method exhibited higher number of spots, but its yield was far from satisfactory, especially when taken into account the reproducibility with limited amount of material. With this method, we observed high values of total soluble proteins (Table II), but according to Sheoran et al. (2009) this value may be altered by the presence of contaminants and little peptides.

The analysis of protein yield showed that the TCA/Acetone method was the most efficient for both tomato leaves (16.96 $\left.\mathrm{mg} \mathrm{gfw}^{-1}\right)$ and roots $\left(3.06 \mathrm{mg} \mathrm{gfw}^{-1}\right)$. In a comparison study of 4 extraction methods for soybean, Natarajan et al. (2005) reported that the TCA/Acetone method exhibited the highest protein resolution and spot intensity of all proteins, corroborating our results. Additionally, several less abundant and high molecular weight proteins were clearly resolved and strongly detected using the TCA methods. These results led us to elect this as the most suitable protocol for performing 2-DE analysis in tomato. Although the TCA/Acetone method was found to be the most efficient method, we suggest further downstream analysis, such as protein identification by mass spectrometry to confirm the efficiency of the protein extraction method, once Sheoran et al. (2009) reported MOWSE score variation, which occasionally results in non-significant protein identification for the same spot according to the protein extraction method employed.

Based on results obtained under the conditions tested, we concluded that the protocol using TCA/ Acetone extraction resulted in the best extraction efficiency and greater protein separation using twodimensional gel electrophoresis. Another advantage is that this protocol is the less time consuming among the ones tested and is now standardized for limited amounts of tomato plant tissue. Therefore, the use of TCA/Acetone extraction protocol combined with the IEF protocol described here for extraction and separation of tomato cv MT proteins may facilitate tomato proteomic research and guide protocols for other complex plant materials. Additionally, the suggested proteomic method approach may be used as a starting point for proteomic studies of other related plant species.

\section{ACKNOWLEDGMENTS}

This work was funded by grant 09/54676-0, Fundação de Amparo à Pesquisa do Estado de São Paulo (FAPESP). We thank Conselho Nacional de Desenvolvimento Científico e Tecnológico (CNPqBrazil) (R.A.A and M.B.V) and FAPESP (G.C. and D.S) for the fellowship and scholarships granted.

\section{RESUMO}

A proteômica é uma área incrível da ciência cujas aplicações vêm avançando para diversos propósitos. Um aspecto crucial para se alcançar boa resolução proteômica é o estabelecimento de uma metodologia que resulte na melhor qualidade e ampla representação das proteínas totais. Outro aspecto importante é que em muitos estudos quantidades limitadas de tecido e de proteínas totais no tecido a ser estudado são encontradas, tornando difícil a análise. Com o objetivo de testar diferentes parâmetros, combinações usando mínimas quantidades 
de tecido com 4 protocolos para extração protéica de folhas e raízes de tomateiro (Solanum lycopersicum L.) foram avaliadas com atenção especial para a capacidade de remover interferentes e atingir resolução adequada em eletroforese bidimensional, bem como rendimento satisfatório de proteínas. A avaliação dos protocolos de extração revelou grandes diferenças na quantidade de proteínas obtidas por cada um. O protocolo TCA/acetona mostrou ser o protocolo mais eficiente, que permitiu a detecção de 211 "spots" para folhas e 336 para raízes utilizando $500 \mu \mathrm{g}$ de proteína de folhas e $800 \mu \mathrm{g}$ de proteínas de raiz por gel.

Palavras-chave: eletroforese bidimensional, proteínas, otimização de protocolo, tomateiro.

\section{REFERENCES}

Amalraj RS, Selvaraj N, Veluswamy GK, Ramanujan RP, Muthurajan R, Palaniyandi M, Agrawal GK, RAKWAL R AND VISWANATHAN R. 2010. Sugarcane proteomics: establishment of a protein extraction method for 2-DE in stalk tissues and initiation of sugarcane proteome reference map. Electrophoresis 31: 1959-1974.

ARruda SCC, BARbosa HB, AZEVEdo RA AND ARrudA MAZ. 2013. Comparative studies focusing on transgenic through cp4EPSPS gene and non-transgenic soybean plants: An analysis of protein species and enzymes. J Proteomics 93: 107-116.

AzEVEDo RA. 2012. Publications in the field of Agrarian Sciences in the Anais da Academia Brasileira de Ciências: what next? An Acad Bras Cienc 84: 1-3.

Barbosa HS, De Souza DLQ, KoOlen HHF, Gozzo FC AND ARRUDA MAZ. 2013. Sample preparation focusing on plant proteomics: extraction, evaluation and identification of proteins from sunflower seeds. Anal Methods 5: 116.

BRADFORD MM. 1976. A rapid and sensitive method for the quantitation of microgram quantities of protein utilizing the principle of protein-dye binding. Anal Biochem 72: 248-254.

CANDiAno G, BRUSCHI M, MusAnte L, SANTUCCI L, GHIGGERI GM, CARNEMOLLA B, ORECCHIA P, ZARDI L AND RIGHETTI PG. 2004. Blue silver: a very sensitive colloidal Coomassie G-250 staining for proteome analysis. Electrophoresis 25: $1327-1333$.

CARVAlho RF, Monteiro CC, CAETANo AC, Dourado MN, Gratão PL, Haddad CRB, PERES LEP AND AZEVEdo RA. 2013. Leaf senescence in tomato mutants as affected by irradiance and phytohormones. Biol Plant 57: 749-757.

Da Silva MAO, Garcia JC, De SOUZa GHMF, EBERLin MN, GOZZO FC AND ARRUDA MAZ. 2009. Evaluation of sample preparation protocols for proteomic analysis of sunflower leaves. Talanta 80: 1545-1551.
Dourado MN, Martins PF, Quecine MC, Piotto FA, SouZA LA, Franco MR, TEZotTo T AND AZEVEdo RA. 2013. Burkholderia sp. SCMS54 reduces cadmium toxicity and promotes growth in tomato. Ann Appl Biol 163: 494-507.

Dourado MN, Souza LA, Martins PF, Peters LP, Piotto FA AND AZEVEDO RA. 2014. Burkholderia sp. SCMS54 triggers a global stress defense in tomato enhancing cadmium tolerance. Water Air Soil Pollut 225: 2159.

Gratão Pl, Monteiro CC, CARVAlho RF, Tezotto T, Piotto FA, Peres LEP AND AZEVEdo RA. 2012. Biochemical dissection of diageotropica and Never ripe tomato mutants to Cd-stressful conditions. Plant Physiol Biochem 56: 79-96.

Gratão Pl, Monteiro CC, Rossi ML, Martinelli AP, Peres LEP, MEdici LO, LEA PJ AND AZEVEdo RA. 2009. Differential ultrastructural changes in tomato hormonal mutants exposed to cadmium. Environ Exp Bot 67: 387-394.

HOAGLAND D AND ARNON DI. 1950. The water-culture method for growing plants without soil. University of California, California Agricultural Experiment Station, 1950, Circular no. 347,32 p.

KIM JY ET AL. 2013. Depletion of abundant plant RuBisCO protein using the protamine sulfate precipitation method. Proteomics 13: 2176-2179.

LAEMMLI UK. 1970. Cleavage of structural proteins during the assembly of the head of bacteriophage T4. Nature 227: 680-685.

LeE DG, Houston NL, Stevenson SE, Ladics GS, McClain S, PRIVAlle L AND THELEN JJ. 2010. Mass spectrometry analysis of soybean seeds proteins: optimization of gelfree quantitative workflow. Anal Methods 2: 1577-1583.

LeE J, Jiang W, QIaO Y, ChO Y, WOO M, ChIn J, KWON S, Hong S, CHOI I AND KoH H. 2011. Shotgun proteomic analysis for detecting differentially expressed proteins in the reduced culm number rice. Proteomics 11: 455-468.

Luque-Garcia JL, CABeZas-SANChez P AND CAMARA C. 2011. Proteomics as tool for examining the toxicity of heavy metals. Trends Anal Chem 30: 1-14.

Meissner R, JaCobson Y, Melamed S, LeVyatuv S, Shalev G, Ashri A, ELKIND Y AND LEVY A. 1997. A new model system for tomato genetics. Plant J 12: 1465-1472.

Monteiro CC, Carvalho RF, Gratão PL, Carvalho G, Tezotto T, Medici LO, Peres LEP AND Azevedo RA. 2011. Biochemical responses of the ethylene-insensitive Never ripe tomato mutant subjected to cadmium and sodium stresses. Environ Exp Bot 71: 306-320.

MONTEIRO CC ET AL. 2012. Biochemical and histological characterization of tomato mutants. An Acad Bras Cienc 84: 573-585.

NATARAJAN S, Xu CP, CAPERNA TJ AND GARRETT WA. 2005. Comparison of protein solubilization methods suitable for proteomic analysis of soybean seed proteins. Anal Biochem 342: 214-220.

Nogueirol RC, Monteiro FA, Gratão PL, Borgo L AND AzEVEDO RA. 2015. Tropical soils with high aluminum concentrations cause oxidative stress in two tomato genotypes. Environ Monit Assess 187: 73. 
PALMA JM, CORPAS FJ AND DEL Río LA. 2011. Proteomics as an approach to the understanding of the molecular physiology of fruit development and ripening. J Proteomics 74: 1230-1243.

PAVLIĆEVIĆ MŽ, STANOJEVIĆ SP AND VUCELIĆ-RADOVIĆ BV. 2013. Influence of extraction method on protein profile of soybeans. Hem Ind 67: 687-694.

PAVOKOVIĆ D, KRIŽNIK B AND KRSNIK-RASOL M. 2012. Evaluation of protein extraction methods for proteomic analysis of non-model recalcitrant plant tissues. Croat Chem Acta 85: 177-183.

Persia D, CAi G, CAsino DC, FAleri C, Willemse TMM AND CRESTI M. 2008. Sucrose synthase is associated with the cell wall of tobacco pollen tubes. Plant Physiol 147: 1603-1618.

RoAn SF, HSIUNG TC, YANG KY, LIU WT, CHANG IF, WU CT AND WAKANA A. 2013. Establishment of the optimal conditions for two-dimensional gel electrophoresis of papaya seed proteome. J Fac Agr Kyushu U 58: 239-246.

Rodrigues EP, TORRES AR, BATISTA JSD, HUERGO L AND HUNGRIA M. 2012. A simple, economical and reproducible protein extraction protocol for proteomics studies of soybean roots. Genet Mol Biol 35: 348-352.

Rose JKC, BASHIR S, GIOVANNONI JJ, JAHN MM AND SARAVANAN RS. 2012. Tackling the plant proteome: practical approaches, hurdles and experimental tools. Plant J 39: 715-733.
SARAVANAN RS AND RoSE JKC. 2004. A critical evaluation of sample extraction techniques for enhanced proteomic analysis of recalcitrant plant tissues. Proteomics 4: 25222532.

SHEORAN IS, ROSS ARS, OLSON DJH AND SAWHNEY VK. 2009. Compatibility of plant protein extraction methods with mass spectrometry for proteome analysis. Plant Sci 176: 99-104.

TABB DL. 2013. Quality assessment for clinical proteomics. Clin Biochem 46: 411-420.

TGC - The Tomato Genome Consortium. 2012. The tomato genome sequence provides insights into fleshy fruit evolution. Emerging model organisms: Tomato (Solanum lycopersicum) a model fruit-bearing crop. Nature 485: 635-641.

Wouters B, Vanhoutte DJD, Aarnoutse P, Visser A, Stassen C, DeVreese B, KoK WTH, Schoenmakers PJ AND EELTINKA S. 2013. Visualization procedures for proteins and peptides on flat-bed monoliths and their effects on matrix-assisted laser-desorption/ionization time-of-flight mass spectrometric detection. J Chromatogr A 1286: 222-228.

Xu C, Xu Y and Huang B. 2008. Protein extraction for twodimensional gel electrophoresis of proteomic profiling in turfgrass. Crop Sci 48: 1608-1614. 
